\title{
Metal levels and accumulation patterns of sea lamprey ammocoetes (Petromyzon marinus Linnaeus, 1758) from a tidal freshwater habitat
}

\author{
Mário Jorge Araújo ${ }^{1 *}$, Pedro Reis ${ }^{1}$, Ana Catarina Braga ${ }^{1}$ and Carlos Antunes ${ }^{1,2,3}$ \\ ${ }^{1}$ CIMAR-LA/CIIMAR Interdisciplinary Centre of Marine and Environmental Research, Rua dos Bragas, 289, 4050-123 Porto, \\ Portugal \\ 2 Gallaecia University School, Largo das Oliveiras, 4920-275 Vila Nova de Cerveira, Portugal \\ 3 Aquamuseum of River Minho, Parque do Castelinho, 4920-290 Vila Nova de Cerveira, Portugal
}

Received 4 March 2013; Accepted 14 May 2013

\begin{abstract}
Ammocoetes of sea lamprey (Petromyzon marinus Linnaeus, 1758) from an assumedly pristine tidal freshwater habitat were used for determination of metal levels and accumulation patterns with size. The individuals were collected during the winter of 2011 in river Minho (Iberian Peninsula, Southwest of Europe) and the levels of metals $(\mathrm{Cd}, \mathrm{Cu}, \mathrm{Cr}, \mathrm{Fe}, \mathrm{Pb}, \mathrm{Mn}$ and $\mathrm{Zn})$ in the whole body were analysed by atomic absorption spectrometry. Fe was the metal with highest levels (maximum of $1438 \mathrm{ppm}$ ), while $\mathrm{Cd}$ and $\mathrm{Pb}$ were the lowest accumulated elements (overall means of $0.093 \pm 0.065 \mathrm{ppm}$ and $0.259 \pm 0.094 \mathrm{ppm}$, respectively). Larger ammocoetes seemed prone to accumulate $\mathrm{Cu}, \mathrm{Fe}$ and $\mathrm{Mn}(P<0.05)$. $\mathrm{Pb}$ and $\mathrm{Zn}$ levels also seemed to increase with ammocoetes size; however, statistical differences were not found between size classes $(P>0.05)$.
\end{abstract}

Key words: Absorption spectroscopy / bioaccumulation / heavy metals / Minho / Miño

\section{Introduction}

The sea lamprey (Petromyzon marinus Linnaeus, 1758) is widely distributed along North Atlantic and is present in several European rivers from Norway to the Iberian Peninsula and in Mediterranean basins (Hardisty, 1986). The larvae or ammocoetes of sea lamprey remain buried in soft substrates and filter-feed on algae, micro-organisms and organic detritus during a period of 4-7 years, prior to adult marine stage (Almeida and Quintella, 2002; Almeida et al., 2008).

Metals occur naturally worldwide, however, their concentrations occur far higher than natural levels in some ecosystems, mainly due to anthropogenic activities (USDA, 2000; Mason, 2002). Some metals are essential elements (e.g. $\mathrm{Zn}$ and $\mathrm{Cu}$ ) for reproduction and growth of living organisms; however, most metals are toxic when in high concentrations. The levels of these elements in sediments, water and aquatic organisms should be monitored in order to study potential changes induced in living beings (Clark, 2002; Mason, 2002). Most toxicological studies with sea lamprey used landlocked populations and aimed at identifying effective lampricides;

\footnotetext{
*Corresponding author: major.a3@gmail.com.
}

however, few works address metal accumulated by anadromous sea lampreys in their native ranges (Holmes and Youson, 1996; Andersen et al., 2010; Pedro et al., 2013).

The absorption of waterborne metals occurs mainly through the skin, viscera and gills of fish and the absorption of metals by filter-feeding organisms is usually higher when compared with other aquatic organisms (Naimo, 1995; Holmes and Youson, 1996). Toxicity studies concluded that ammocoetes of Pacific lamprey Entosphenus tridentatus (Richardson, 1836) were relatively insensitive to several chemicals when compared with other aquatic species (Andersen et al., 2010). Therefore, ammocoetes should also be prone to accumulating some metals retained in interstitial waters.

River Minho (or "Miño" in Spanish) works as a natural boundary between Portugal and Spain for $75 \mathrm{~km}$. Tidal freshwater ecosystems occur in the upper estuary of River Minho which are used by a range of species with conservation importance for spawning, refuge and feeding (Sousa et al., 2008). However, these ecosystems are often threatened by several anthropogenic activities (such as farming, industrial activities and navigation), which promote higher concentrations of contaminants (Clark, 2002). The thinner granulometry of such areas is 


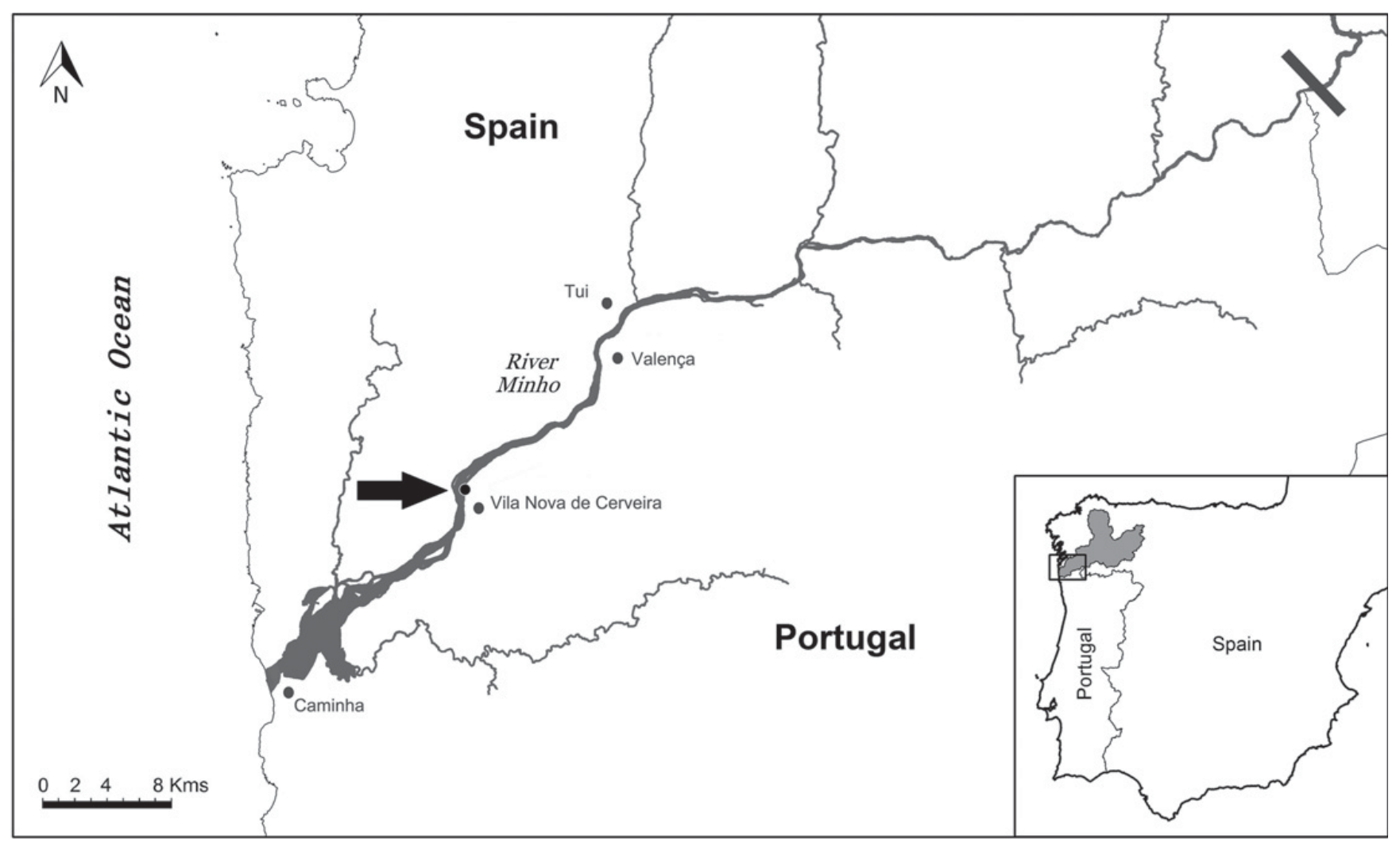

Fig. 1. Study area (arrow). Sea lampreys are restricted to the river section of downstream Frieira dam (bar).

particularly vulnerable to metal accumulation (Reis et al., 2009). Nonetheless, river Minho is still considered a low contaminated area regarding metals and can be used as reference to other areas (Reis et al., 2009).

As far as we know, metal levels of $\mathrm{Cd}, \mathrm{Cr}, \mathrm{Mn}, \mathrm{Pb}$ and $\mathrm{Zn}$ in ammocoetes of $P$. marinus throughout its native range and metal concentrations in aquatic species of river Minho are still unavailable. Therefore, the objectives of this work were: (i) to determine the levels of metals $(\mathrm{Cd}, \mathrm{Cr}, \mathrm{Cu}, \mathrm{Fe}, \mathrm{Mn}, \mathrm{Pb}$ and $\mathrm{Zn}$ ) of sea lamprey $P$. marinus ammocoetes from river Minho and (ii) to discuss their accumulation along this stage.

\section{Methods}

The river Minho is located in the northwestern corner of the Iberian Peninsula, in SW Europe, flowing westward from the Cantabrian Mountains (north of Spain) to the Atlantic Ocean (Fig. 1). The total area of the Minho watershed is $17100 \mathrm{~km}^{2}$ and the mainstream is $300 \mathrm{~km}$ long. The available habitat for native anadromous sea lampreys in river Minho is restricted to the downstream section (approx. $75 \mathrm{~km}$ in length), as migrating adults are unable to overcome the first impassable barrier ("Frieira" dam) (Sousa et al., 2012; Araújo et al., 2013).

The sea lampreys were collected in tidal freshwater habitats $\left(41^{\circ} 57.90^{\prime} \mathrm{N} ; 8^{\circ} 44.40^{\prime} \mathrm{W}\right.$ and $41^{\circ} 56.26^{\prime} \mathrm{N}$; $\left.8^{\circ} 45.07^{\prime} \mathrm{W}\right)$ approx. $14 \mathrm{~km}$ upstream river mouth, with dip net (mesh size: $1 \mathrm{~mm}$ ) in the river Minho from the
Portuguese bank between 3 and 10 February 2011 (overall $n=145$ ) during low tide (depth ranging from 0 to $0.50 \mathrm{~m}$ ). The surface water abiotic variables (temperature, $\mathrm{pH}$, conductivity and dissolved oxygen) were measured prior to sampling using a multi-parametric sea gauge YSI 6820 (Brannum Lane, Yellow Springs, OH). The individuals were transported alive to Aquamuseu do rio Minho (Vila Nova de Cerveira, Portugal) and after anaesthetic bath with Tricaine methanesulfonate (MS-222) their length $(0.5 \mathrm{~mm})$ and weight were determined $(0.01 \mathrm{~g})$. The condition factor $K$ was estimated using the equation: $K=W \cdot L^{-3} \times 100$, where $W$ is the whole body wet weight in $\mathrm{g}$ and $L$ total length in $\mathrm{cm}$ (Froese, 2006).

Length of time of exposure to environmental metals is reported to influence the amounts of some elements in aquatic organisms (Luoma, 1983; Clark, 2002; Durrieu et al., 2005). Therefore, whole body samples of randomly chosen ammocoetes from three distinct size classes with $35 \mathrm{~mm}$ of interval (60-95 mm, 95-130 mm and 130-165 mm; $n=3$ for each class) which probably correspond to three different age-classes (Holmes and Youson, 1996) were selected to proceed with metal analyses. The determination of metal concentrations followed the method of Reis and Almeida (2008) and Reis et al. (2009). The samples were freeze dried (FreeZone Plus 12; Bulk Tray Dryer, Labconco, Kansas City, MO, USA) and homogenized with commercial mills. Triplicates (300 mg/replicate) of each sample were digested in high pression Teflon bombs (model 4782, Parr) at $500 \mathrm{~W}$ microwave (NE-1037, Panasonic): two consecutive digestions of $5 \mathrm{~min}$ each with 
Table 1. Limits of detection and quantification of the analytical methods and the metal concentrations in the certified reference materials. LOD, limit of detection; LOQ, limit of quantification; concentrations are expressed in ppm as mean $\pm \mathrm{SD}$.

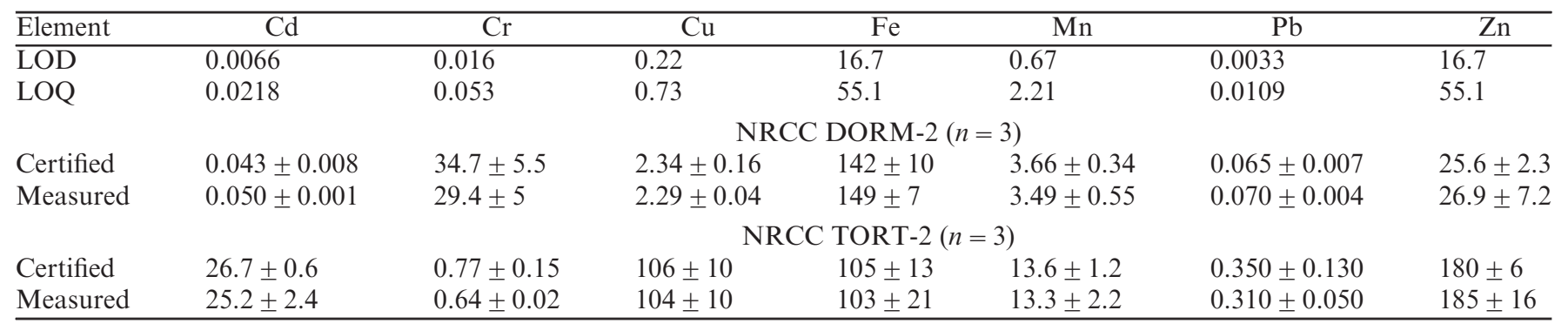

$5 \mathrm{~mL}$ pure nitric acid and one ice cooling bath of at least $2 \mathrm{~h}$ between digestions (Reis and Almeida, 2008). Metal levels of each individual were analysed by Atomic Absorption Spectrometry (AAS, SpectrAA 220 FS, Varian), coupled with deuterium lamp for background correction, with flame atomization (FAAS, Marck 7, Varian) and electrothermal atomization (Autosampler 110, Varian), depending on the metal levels of sample and element to be determined. The certified reference materials used to ensure suitability of the analytical method for metal analyses were NRCC Dorm-2 (Dogfish muscle tissue) and NRCC Tort-2 (Lobster hepatopancreas tissue). For each solution, the software Varian was set for a precision lower than $10 \%$ between readings with a maximum of four readings per replica to ensure reproducibility of readings and metals were expressed in ppm (in dry weight basis). The limits of detection (LOD) and quantification (LOQ) are shown in Table 1 and were determined using the method of Reis et al. (2009).

The existence of statistical differences between size classes was performed after testing for normality (Kolgomorov-Smirnov Test) and for homogeneity of variance (Bartlett's Test) with one-way analysis of variance (ANOVA) followed by Tukey test when significant differences were detected. A $P<0.05$ was considered significant. "Minitab ${ }^{\circledR}$ Release 14.12.0" software (Minitab Inc.) was used.

\section{Results and discussion}

The water temperature at sampling time in river Minho ranged from $8.1^{\circ} \mathrm{C}$ to $8.9^{\circ} \mathrm{C}$. The water $\mathrm{pH}$ was neutral $(7.1 \pm 0.17$, mean $\pm \mathrm{SD})$ and the dissolved oxygen was $8.6 \pm 1.22 \mathrm{mg} . \mathrm{L}^{-1}$. The conductivity results were in accordance with previous works in the same area $\left(75 \pm 6.7 \mu \mathrm{S} . \mathrm{cm}^{-1}\right)$ (Almeida et al., 2008; Reis et al., 2009).

The log transformed $L-W$ relationship of ammocoetes was $\log W(\mathrm{~g})=-5.124+2.67 \log L(\mathrm{~mm})\left(R^{2}=0.98\right.$, $n=145)$. The size of the ammocoetes used in metal determination ranged from 0.79 to $6.89 \mathrm{~g}$ in weight $(2.80 \pm 2.15$, mean \pm SD) and from 74 to $165 \mathrm{~mm}$ in total length $(112 \pm 32$, mean $\pm \mathrm{SD})$. The condition factor ranged from 0.14 to 0.19 .

The patterns of mean metal occurrence in order of increasing concentrations in the ammocoetes were as follows: $\mathrm{Cd}<\mathrm{Pb}<\mathrm{Cr}<\mathrm{Cu}<\mathrm{Mn}<\mathrm{Zn}<\mathrm{Fe}$. This pattern slightly differs from metal levels in sediment samples of river Minho ( $\mathrm{Cd}<\mathrm{Cu}<\mathrm{Cr}<\mathrm{Pb}<\mathrm{Zn}<\mathrm{Mn}<<\mathrm{Fe}$ ) (Paiva et al., 1993; Moreno et al., 2005; Lyra, 2007; Mil-Homens et al., 2012).

The concentration of $\mathrm{Cd}$ apparently does not change with ammocoete size class $(P=0.072$, Fig. 2$)$ and the overall levels (ranging from 0.007 to $0.218 \mathrm{ppm}$ ) were much lower than those found in muscle of sea lamprey spawners (ranging approx. from 6.5 to $13 \mathrm{ppm}$ ) (Pedro et al., 2013) which is in accordance with the literature, as the concentrations of this metal are referred to increase with age of fish as the excretion of this element is difficult (Eisler, 1985; Mason, 2002). The amounts of $\mathrm{Cd}$ in the muscle of Mugil cephalus (Linnaeus, 1758) living in metalcontaminated ecosystems range from 0.08 to $0.6 \mathrm{ppm}$ (Dural et al., 2007; Ambedkar and Muniyan, 2011) and reach $5.2 \mathrm{ppm}$ in the whole body of benthic flounder Platichthys flesus (Linnaeus, 1758) (Eisler, 1985). These values are relatively higher to those found in ammocoetes, which might be a consequence of the low values of this element in river Minho water and sediments $(<0.0005$ ppm and ranging from 0.03 to $0.66 \mathrm{ppm}$, respectively) (Paiva et al., 1993; Lyra, 2007; Santos et al., 2012).

It is assumed that freshwater fish species can regulate Cr over a wide range of environmental conditions and the concentrations of this element tend to increase along the trophic web (Eisler, 1986; Irwin et al., 1997). Aquatic species show a wide range of $\mathrm{Cr}$ concentrations in their tissues. Ambedkar and Muniyan (2011) report Cr levels ranging from 0.70 to $1.28 \mathrm{ppm}$ in the muscle of several freshwater species from contaminated areas and Tiller et al. (2004) obtained $\mathrm{Cr}$ as high as $9.4 \mathrm{ppm}$ in Oncorhynchus spp. The concentrations of $\mathrm{Cr}$ in ammocoetes ranged from 0.270 to $1.57 \mathrm{ppm}$ and apparently do not seem to change with size $(P=0.500)$. As $\mathrm{Cr}$ is one of the metals with lower concentrations in river Minho (mean sediment concentrations ranging from 13.9 to $41.0 \mathrm{ppm}$ ) (Lyra, 2007; Moreno et al., 2005) at this time it is difficult to conclude the capacity of ammocoetes to regulate or accumulate $\mathrm{Cr}$. Therefore, study of the response of ammocoetes to environmental levels of $\mathrm{Cr}$ is still needed.

$\mathrm{Cu}$ and $\mathrm{Fe}$ values in ammocoetes of sea lamprey from Minho watershed showed similar ranges to those of sea lampreys ammocoetes from New Brunswick in Canada (Holmes and Youson, 1996). Interspecific differences were 

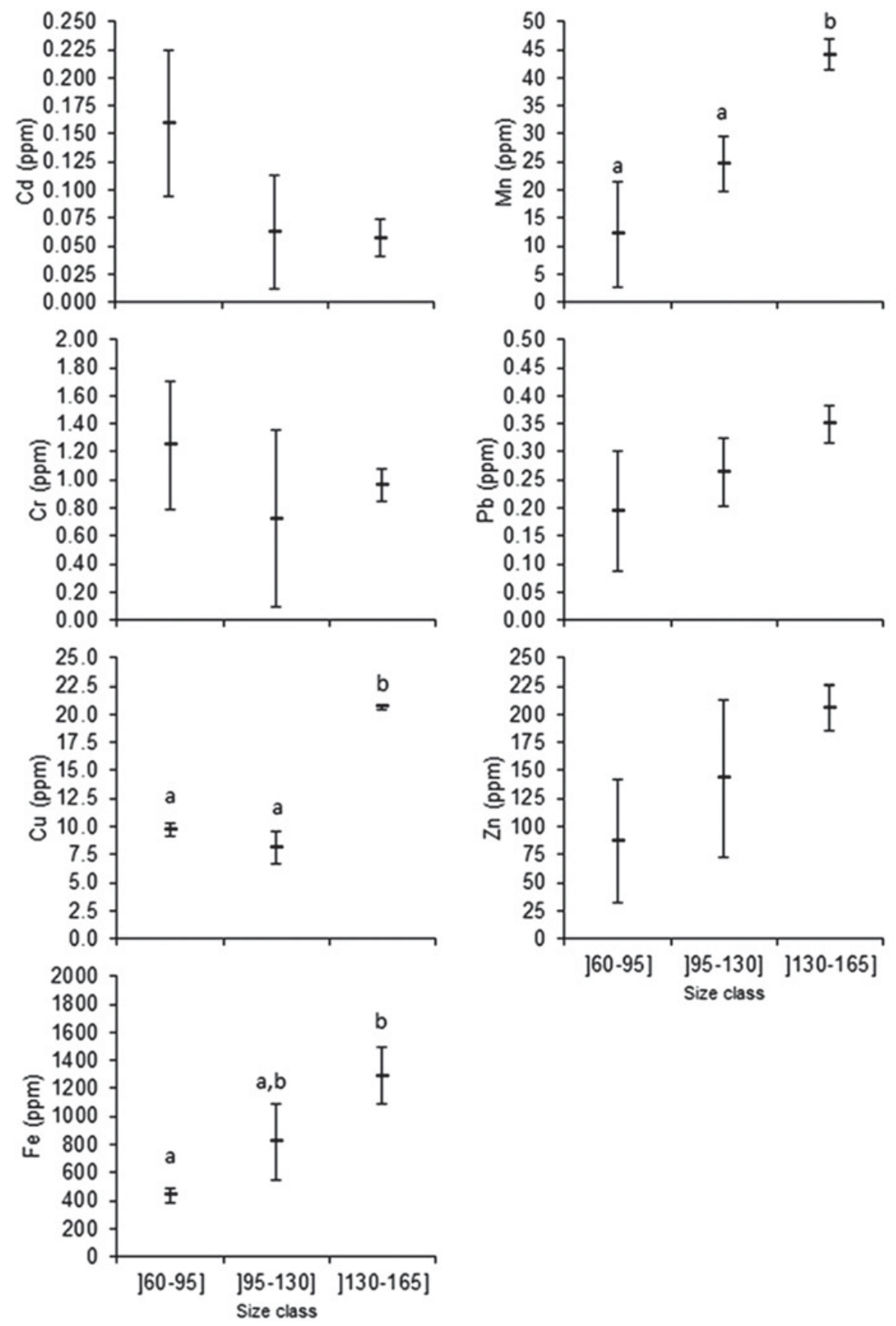

Fig. 2. Concentrations of $\mathrm{Cd}, \mathrm{Cr}, \mathrm{Cu}, \mathrm{Fe}, \mathrm{Mn}, \mathrm{Pb}$ and $\mathrm{Zn}$. Size classes in mm. Bars represent mean $\pm \mathrm{SD}$. Different letters above bars indicate existence of statistical significance between class for each metal $(P<0.05)$.

previously reported in toxicological studies among lamprey species regarding metal accumulation as Fe levels are higher in lamprey Geotria australis (Gray, 1851) tissues than in sea lampreys (Macey and Potter, 1986; Sargent and Youson, 1986). The continuous feeding on blood by adult parasitic lampreys leads them to ingest high quantities of $\mathrm{Fe}$ and therefore sea lampreys reach $\mathrm{Fe}$ concentrations serum as high as $94500 \mathrm{ppm}$ (Macey and Potter, 1986; Holmes and Youson, 1996; Andersen et al., 1998). Ammocoetes from Minho also seemed to highly accumulate $\mathrm{Fe}(F[2,7]=14.04, P=0.005)$, which is reported to correlate with length of time they filter-feed (Tsioros and Youson, 1997). Moreover, Fe is highly abundant in the environment (ranges from 7551 to $34500 \mathrm{ppm}$ in sediment samples of Minho) (Moreno et al., 2005; Lyra, 2007) and it was previously reported that $\mathrm{Fe}$ accumulation in ammocoetes is site-specific and may reflect different contributions of sediment and waterborne metals (Holmes and Youson, 1996). $\mathrm{Cu}$ is less abundant in freshwater ecosystems than $\mathrm{Fe}$ (maximum of $36 \mathrm{ppm}$ of $\mathrm{Cu}$ in sediment samples of Minho) (Moreno et al., 2005). Nevertheless, ammocoetes seemed to accumulate $\mathrm{Cu}$ during the freshwater stage (values ranging from 6.5 to $20.8 \mathrm{ppm}, \quad F[2,7]=147.36, \quad P=0.000)$ and also seem to reach higher values than during the marine stage (spawning sea lamprey muscle concentrations of $\mathrm{Cu}$ range from 2.4 to $3.5 \mathrm{ppm}$ ) (authors unpublished data; Pedro et al., 2013). 
Mn is an essential metal for metabolism of amino acids, lipids and carbohydrates; however, reproductive malfunctions can occur when in high concentrations (Srivastava and Agrawal, 1983). Mn in sediments of river Minho is fairly high (maximum of $302 \mathrm{ppm}$ in river Minho) (Moreno et al., 2005; Reis et al., 2009) and enrichments with this metal might occur in interstitial waters of estuarine habitats (Widerlund and Ingri, 1996; Gaillardet et al., 2011). Ammocoetes live and feed in this layer and seem to accumulate this metal during this stage (values ranging from 5.7 to $46.4 \mathrm{ppm}, F[2,8]=19.70 ; P=0.02$ ).

Once in blood circulation and after intestinal absorption, $\mathrm{Pb}$ will be deposited in the liver and skeletal bodies, causing cellular disruption and damages to mitochondria, altering metabolism and replacing lipids and essential metals such as Mn and Zn (Pokras and Kneeland, 2009). A great variability on $\mathrm{Pb}$ levels was reported to occur in adult riverine lamprey Lampetra fluviatilis (Linnaeus, 1758) (Protasowicki et al., 2011). A relatively wide range of $\mathrm{Pb}$ concentrations in ammocoetes of sea lamprey was also obtained (values ranging from 0.129 to $0.374 \mathrm{ppm}$ ), which apparently increase with size (Fig. 2). However, such a fact was not statistically confirmed $(P=0.191)$.

Both ammocoetes and adult sea lampreys seem to highly accumulate $\mathrm{Zn}$ (overall values ranging from 48.3 to $218.6 \mathrm{ppm}$ in ammocoetes, values ranging from 19 to $33 \mathrm{ppm}$ in adult sea lamprey muscle and from 110 to 137 ppm in gonads; authors unpublished data; Pedro et al., 2013). Ammocoetes might be capable of regulating this metal due to their use in physiological functions related to the regulation of $\mathrm{pH}, \mathrm{CO}_{2}$ transport, protein replication and DNA transcription (Hogstrand and Wood, 1996; Dural et al., 2007). An apparent pattern of accumulation of this metal seemed to occur; however that fact was not statistically confirmed $(P=0.085)$, because a wide range of concentrations were found in ammocoetes. This was similar to previously reported studies with adult sea and riverine lampreys (Protasowicki et al., 2011; Pedro et al., 2013).

\section{Conclusions}

The levels of metals in sea lampreys ammocoetes and in other aquatic species from river Minho were scarce until this moment. Our results point out that ammocoetes of sea lamprey P. marinus from Minho watershed can accumulate considerable quantities of some elements, but mainly $\mathrm{Fe}$ and $\mathrm{Zn}$ and might work as input of metals into trophic webs. Low concentrations of $\mathrm{Cr}$ and $\mathrm{Pb}$ are in accordance with consideration of the Minho watershed as a metal uncontaminated and a metal-pristine area (Reis et al., 2009; Mil-Homens et al., 2012; Santos et al., 2012).

The outstanding accumulation of some metals (such as $\mathrm{Fe}$ ) and the capacity to detoxify and possibly regulate some elements (Al and possibly $\mathrm{Zn}$ ) (Holmes and Youson, 1996) might compromise the use of this organism as an indicator of contamination and such possibility should be further studied.
Acknowledgements. The authors would like to express thanks to António Roleira and Eduardo Martins for sampling help and P. Laffaille and two anonymous referees for helpful suggestions on the manuscript. The authors also acknowledge project MIGRANET (MIGRANET-SOE2-P2-288-2011-020) for financial support.

\section{References}

Almeida P.R. and Quintella B.R., 2002. Larval habitat of the sea lamprey (Petromyzon marinus L.) in the River Mondego (Portugal). In: Collares-Pereira M.J., Coelho M.M. and Cowx I.G. (eds.), Freshwater Fish Conservation: Options for the Future - Fishing News Books, Blackwell Science, Oxford, 121-130.

Almeida P.R., Tomaz G., Andrade N.O. and Quintella B.R., 2008. Morphological analysis of geographic variation of sea lamprey ammocoetes in Portuguese river basins. Hydrobiologia, 602, 47-59.

Ambedkar G. and Muniyan M., 2011. Accumulation of metals in the five commercially important freshwater fishes available in vellar river, TamilNadu, India. Arch. Appl. Sci. Res., 3, 261-264.

Andersen H.B., Caldwell R.S., Toll J., Do T. and Saban L., 2010. Sensitivity of lamprey ammocoetes to six chemicals. Arch. Environ. Contam. Toxicol., 59, 622-631.

Andersen Ø., Pantopoulos K., Kao H.T., Muckenthaler M., Youson J. and Pieribone V., 1998. Regulation of iron metabolism in the sanguivore lamprey Lampetra fluviatilis molecular cloning of two ferritin subunits and two ironregulatory proteins (IRP) reveals evolutionary conservation of the iron-regulatory element (IRE)/IRP regulatory system. Eur. J. Biochem., 254, 223-229.

Araújo M.J., Ozório R.O.A., Bessa R.J.B., Kijjoa A., Gonçalves J.F.M. and Antunes C., 2013. Nutritional status of adult sea lamprey (Petromyzon marinus, Linnaeus, 1758) during spawning migration in the Minho River, NW Iberian Peninsula. J. Appl. Ichthyol., 1-7, DOI: 10.1111/ jai.12192.

Clark R.B., 2002. Marine Pollution (5th edn,), Oxford University Press, Oxford, $340 \mathrm{p}$.

Dural M., Göksu M.Z.L. and Özak A.A., 2007. Investigation of heavy metal levels in economically important fish species captured from the Tuzla lagoon. Food Chem., 102, 415-421.

Durrieu G., Maury-Brachet R., Girardin M., Rochard E. and Boudou A., 2005. Contamination by heavy Metals (Cd, Zn, $\mathrm{Cu}$, and $\mathrm{Hg}$ ) of eight fish species in the Gironde Estuary (France). Estuaries, 28, 581-591.

Eisler R., 1985. Cadmium hazards to fish, wildlife, and invertebrates: a synoptic review. U.S. Fish and Wildlife Service Biological Report 85 (1.2). Contaminant Hazard Reviews Report No. 2.

Eisler R., 1986. Chromium hazards to fish, wildlife, and invertebrates: a synoptic review. U.S. Fish and Wildlife Service Biological Report 85 (1.6). Contaminant Hazard Reviews Report No. 6.

Froese R., 2006. Cube law, condition factor and weight-length relationships: history, meta-analysis and recommendations. J. Appl. Ichthyol., 22, 241-253.

Gaillardet J., Viers J. and Dupré B., 2011. Trace elements in river waters. In: Holland H.D. and Turekian K.K. (eds.), Treatise 
on Geochemistry, Vol. 5, Elsevier-Pergamon, Oxford, 293-338.

Hardisty M.W., 1986. Petromyzon marinus. In: Holcik J. (ed.), The Freshwater Fishes of Europe, vol. I. Aula-Verlag, Wiesbaden, 92-116.

Hogstrand C. and Wood C.M., 1996. The physiology and toxicology of zinc in fish. In: Taylor E.W. (ed.), Toxicology of Aquatic Pollution - Physiological, Molecular and Cellular Approaches, University of Birmingham, Birmingham, 61-84.

Holmes J.A. and Youson J.H., 1996. Environmental sources of trace metals in sea lamprey, Petromyzon marinus, larvae in New Brunswick, Canada. Environ. Biol. Fish, 47, 299-310.

Irwin R.J., Van Mouwerik M., Stevens L., Seese M. and Basham W., 1997. Environmental Contaminants Encyclopedia, Chromium VI (Hexavalent chromium) Entry, National Park Service, Water Resources Division, Fort Collins, $\mathrm{CO}, 43 \mathrm{p}$.

Kottelat M. and Freyhof J., 2007. Handbook of European Freshwater Fishes, Kottelat, Cornol and Freyhof, Berlin, $647 \mathrm{p}$.

Luoma S.N., 1983. Bioavailability of trace metals to aquatic organisms - a review. Sci. Total Environ., 28, 1-22.

Lyra F.J., 2007. Caracterização da comunidade de macroinvertebrados bentónicos do estuário do rio Minho - sua relação com a distribuição de poluentes nos sedimentos. ("Characterization of benthic macroinvertebrates community of river Minho estuary - relation with distribution of pollutants in the sediments" in Portuguese). Master Thesis, Sciences Faculty, Oporto University, 109 p.

Macey D.J. and Potter I.C., 1986. Concentrations of non-haem iron in ammocoetes of species representing three extant lamprey families. Comp. Biochem. Physiol., 84A, 77-79.

Mason C.F., 2002. Biology of Freshwater Pollution (4th edn,), Pearson Education Limited, Essex, 387 p.

Mil-Homens M., Costa A.M., Fonseca S., Trancoso M.A., Lopes C., Serrano R. and Sousa R., 2012. Natural heavy metal and metalloid concentrations in sediments of the Minho River estuary (Portugal): baseline values for environmental studies. Environ. Monit. Assess., DOI: 10.1007/ s10661-012-2996-Z.

Moreno F., Araújo M.F., Moreno J., Fatela F. and Drago T., 2005. Caracterização geoquímica de sedimentos superficiais do estuário do Minho e do sapal de Caminha (NW de Portugal) - estimativa do potencial de stress biológico. ("Geochemical characterization of superficial sediments of Minho estuary and Caminha marshland (NW Portugal) estimation of biological stress potential" in Portuguese). In: Proceedings of the XIV Week of Geochemistry/VIII Congress of Geochemistry of Countries of Portuguese Language, University of Aveiro, Portugal, 675-678.

Naimo T.J., 1995. A review of the effects of heavy metals on freshwater mussels. Ecotoxicology, 4, 341-362.

Paiva P.C., Araújo M.C., Dias J.M. and Jouanneau J.M., 1993. Distribuição elementar em sedimentos do rio Minho ("Elemental distribution of river Minho sediments" in Portuguese). In: Proceedings of the II Congress of
Geochemistry of Countries of Portuguese Language, Faculty of Sciences, University of Oporto, Portugal, 561-566.

Pedro S., Caçador I., Quintella B.R., Lança M.J. and Almeida P.R., 2013. Trace element accumulation in anadromous sea lamprey spawners. Ecol. Fresh. Fish, DOI: 10.1111/ eff. 12052

Pokras M.A. and Kneeland M.R., 2009. Understanding lead uptake and effects across species lines: a conservation medicine based approach. In: Watson R.T., Fuller M., Pokras M. and Hunt W.G. (eds.), Ingestion of Lead from Spent Ammunition: Implications for Wildlife and Humans, The Peregrine Fund, Boise, Idaho, USA, DOI: 10.4080/ ilsa.2009.0101.

Protasowicki M., Ciemniak A. and Mamińska M., 2011. Heavy metals in the riverine lamprey lampetra fluviatilis (L. 1758). Rocz. Ochrony Środowisk, 13, 1223-1232.

Reis P. and Almeida C.M.R., 2008. Matrix importance in animal material pre-treatment for metal determination. Food Chem., 107, 1294-1299.

Reis P.A., Antunes J.C. and Almeida C.M.R., 2009. Metal levels in sediments from the Minho estuary salt marsh: a metal clean area?Environ. Monit. Assess., 159, 191-205.

Santos S., Vilar V.J., Alves P., Boaventura R.A. and Botelho C., 2012. Water quality in Minho/Miño River (Portugal/Spain). Environ. Monit. Assess., PMID, 22851194.

Sargent P.A. and Youson J.H., 1986. Quantification of iron deposits in several body tissues of lampreys (Petromyzon marinus L.) throughout the life cycle. Comp. Biochem. Physiol., 83A, 573-577.

Sousa R., Dias S., Guilhermino L. and Antunes C., 2008. Minho river tidal freshwater wetlands: threats to faunal biodiversity. Aquat. Biol., 3, 237-250.

Sousa R., Araújo M.J. and Antunes J.C., 2012. Habitat modifications by sea lampreys (Petromyzon marinus) during the spawning season: effects on sediments. J. Appl. Ichthyol., 28, 766-771.

Srivastava A.K. and Agrawal S.J., 1983. Changes induced by manganese in fish testis. Experientia, 39, 1309-1310.

Tiller B.L., Patton G.W., Dauble D.D. and Paston T.M., 2004. Monitoring Tissue Concentrations of Chromium and Fish Condition in Juvenile Fall Chinook Salmon from the Hanford Reach of the Columbia River. Pacific Northwest National Laboratory, PNNL-14473, Washington, EUA, $39 \mathrm{p}$.

Tsioros K.K. and Youson J.H., 1997. Intracellular distribution of iron (and associated elements) in various cell types of larvae and juveniles of the sea lamprey (Petromyzon marinus). Tissue Cell, 29, 137-162.

USDA [United States Department of Agriculture], 2000. Heavy Metal Soil Contamination. Soil quality - Urban Technical Note No. 3. USDA, Natural Resources Conservation, Auburn, EUA, 7 p.

Widerlund A. and Ingri J., 1996. Redox cycling of Iron and Manganese in sediments of the Kalix River estuary, Northern Sweden. Aquat. Geochem., 2, 185-201. 